\section{Serine Proteases in Systemic Lupus Erythematosus: The Other Half of the Story}

\section{To the Editor:}

The contribution by Troldborg, $e t a l^{1}$ is a valuable addition to our understanding of disease, addressing half the question. Serine proteases do not function in isolation, but are also part of an enzyme-inhibitor interaction ${ }^{2}$. Noting higher enzyme concentrations in their cross-sectional study of patients with systemic lupus erythematosus ${ }^{1}$, direct correlation with nephritis and titers of anti-dsDNA, and inverse correlation with complement $\mathrm{C} 3$, the authors have demonstrated that serine protease levels appear to be markers of disease activity. It may also be worthwhile to assess whether their results reflect disease activity or alteration by the medications used in its treatment, as has been demonstrated for the major serine protease inhibitors, $\alpha$-1-antitrypsin, $\alpha$-2-macroglobulin, and antithrombin $\mathrm{III}^{2,3,4,5,6}$. Their implication of a pathophysiologic involvement is an interesting speculation, especially if a moderating component is considered.

Serine protease inhibitor levels are also proportionate to disease activity $^{7}$ : We and others reported levels proportionate to $\alpha$-1-antitrypsin directly, and $\alpha$-2-macroglobulin and antithrombin III inversely ${ }^{7,8}$. Serine protease inhibitors also have a significant immune modulation effect $^{7}$, but it is unclear if this effect is related to the native molecule or to the complex it forms with serine proteases ${ }^{2,9,10}$. In a relationship analysis of the levels, both components and their combination seem to be a fruitful area for future investigation.

BRUCE ROTHSCHILD, MD, Department of Medicine, Northeast Ohio Medical University, Rootstown, Ohio 44272, USA.

E-mail: spondylair@gmail.com

\section{REFERENCES}

1. Troldborg A, Thiel S, Laska MJ, Deleuran B, Stengaard-Pedersen $\mathrm{K}$. Levels in plasma of the serine proteases and associated proteins of the lectin pathway are altered in patients with systemic lupus erythematosus. J Rheumatol 2015;42:948-51.
2. Rothschild BM. Serine esterase inhibition and immune modulation. Semin Arthritis Rheum 1984;13:274-92.

3. Rothschild BM, Thompson L, Chesney CM, Pifer DD. Drug-induced perturbation of plasma serum esterase inhibitors and fibrinolysis. Curr Therapeut Res 1984;36:588-95.

4. Weindling H, Henry JB. Laboratory test results altered by "The Pill”. JAMA 1974;229:1762-8.

5. Kobayashi N, Takeda Y. Studies of the effects of estradiol, progesterone, cortisol, thrombophlebitis, and typhoid vaccine on synthesis and catabolism of antithrombin III in the dog. Thromb Haemost 1977;37:111-22.

6. Heimbruger N. Proteinase inhibitors of human plasma - their properties and control functions. In: Reich E, Rifkin DB, Shaw E, eds. Proteases and biological control. New York: Cold Spring Harbor; 1975:367-86.

7. Rothschild BM, Thompson LD, Pifer DD, Chesney CM. Perturbation of protease inhibitors and substrates in inflammatory arthritis. Semin Thromb Haemost 1985;11:394-404.

8. Israel L, Samak R, Edelstein R, Bogucki D, Breau JL. [Taken in evidence of the immunosuppressive role of inflammatory proteins. Their pathophysiologic role in cancer]. [Article in French] Ann Med Interne 1981;132:26-9.

9. Havemann K, Dosch HM, Bürger S. [Phytahemaglutinin and serum proteins in lymphocyte culture. I. Proof of promoting and inhibiting serum factors]. [Article in German] Z Ges Exp Med 1970; 153:297-307.

10. Sell S. Stimulation of rabbit peripheral lymphocytes with antisera to alpha-macroglobulin. Intl Arch Allergy Appl Immunol 1970;38:150-7.

J Rheumatol 2016;43:1; doi:10.3899/jrheum.150726 